\title{
PREVALENCE OF Cryptosporidium sp INFECTION IN CATTLEFROM CIAMIS AND TASIKMALAYA WEST JAVA INDONESIA
}

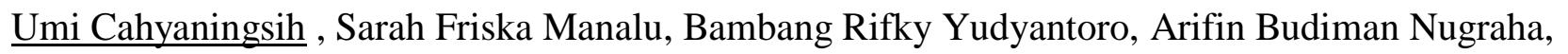
Fadjar Satrija and Yusuf Ridwan

\author{
Faculty of Veterinary Medicine, Bogor Agricultural University, Indonesia \\ e-mail: umicahyaningsih@yahoo.co.id
}

\begin{abstract}
Cryptosporidium sp is a genus of protozoan parasite and causes a diarrheae illness in mammals including animals and humans. The source of infection Cryptosporidiumspis oocysts that is sporulated and infective when excreted in the feces and resulting environmental contamination. Cryptosporidiosis can be transmitted from animals to humans and vice versa (zoonosis). This study aimed to determine the prevalence of cryptosporidiosis in cattle from Ciamis and Tasikmalaya, West Java, Indonesia. The feca 1 specimens from 348 cattle (295 female and 53 male) were randomly collected. The examined for the presence of Cryptosporidium oocysts used floating stool with Sheatersugar and acid - fast staining method (ZiehlNeelsen stain). The results showed that the overall prevalence of infection was $12.07 \%$ ( 42/348). Prevalence of infection related to the age were $14.58 \%, 19.64 \%$ and $9.84 \%$ in cattle less than 6 months, 7-12 months and over 12 months, respectively, also $10.85 \%$ and $18.87 \%$ in female and male, respectively. Although no significant difference exists between the age groups, calves less than 12 months of age are more likely to be infected than over 12 months. The result indicate that Cryptosporidium sp infection is prevalent in Ciamis and Tasikmalaya that could serve as reservoirs for the zooonotic infection in humans.
\end{abstract}

Keywords: cryptosporidium, cattle, prevalence, West Java

\section{INTRODUCTION}

Cryptosporidiosis is one of the most common enteroparasite causing diarrhea in animals and humans, including cattle (Fayer, 2004). Cryptosporidium has become a concern not only because of the direct economic losses associated with the infection, but also from a public health perspective because of the potential for environmental contamination with Cryptosporidium oocysts. (Satin et.al.2008). This study aimed to determine the prevalence of cryptosporidiosis in cattle from Ciamis and Tasikmalaya, West Java, Indonesia, this region where predominant the cattle.

\section{METHODS}

Fecal sampling.

Three hundred fourty eight fecal specimens were collected from rectum or immediately after defecation using disposables plastic gloves. At the time of sampling, labelled the date of sampling, aged and sex of the animal, kept in a coller box then store in the refrigerator before examination.

Detection of oocyst. 
Oocyst were concentrated from feces with floating feces in Sheater Sugar. Briefly, 1 gram of feces from each specimen was mixed with $14 \mathrm{ml}$ of water, and then was centrifugated at $1500 \mathrm{rpm}$ for 10 minutes. Supernatant was aspirated from each suspension, then the pellet was resuspended in $15 \mathrm{ml}$ Sheater Sugar solution, centrifuged again at $1500 \mathrm{rpm}$ for 10 minutes. Five millilitres of supernatant, aspirated from the top of each suspension, was transferred to $15 \mathrm{ml}$ centrifuge tube, and $\mathrm{dH}_{2} \mathrm{O}$ added to reach a final volume of $15 \mathrm{ml}$. Specimens were centrifuged at $1500 \mathrm{rpm}$ for 10 minutes. The pellets were smeared directly onto glass microscope slide and examined for Cryptosporidium oocystswith acid-fast stain (ZiehlNeelsen stain).

\section{RESULTS}

The prevalence results of Cryptosporidium sp oocysts from cattle in Ciamis and Tasikmalaya, West Java are presented in Table 1. Analysis showed an overall pre-valence of $12.07 \%$ in the cattle examined with ZiehlNeelsen staining method.

Table 1. Prevalence of Cryptosporidium sp oocysts from cattle in Ciamis and Tasikmalaya, West Java Indonesia

\begin{tabular}{|c|c|c|c|}
\hline Location & No. examine & No. positive & Prevalence (\%) \\
\hline Ciamis & 145 & 20 & \\
\hline Tasikmalaya & 203 & 22 & \\
\hline Total & 348 & 42 & $12.07 \%$ \\
\hline
\end{tabular}

The prevalence of Cryptosporidium sp related to the sex in females and males were $10.85 \%$ and $18.87 \%$, respectively.(Table 2 ).

Table 2. Prevalence of Cryptosporidium sp oocysts from cattle with sex group.

\begin{tabular}{|l|c|c|c|c|c|}
\hline \multirow{2}{*}{ Sex } & \multicolumn{2}{|c|}{ Location } & No. examine & No.positive & Prevalence(\%) \\
\cline { 2 - 3 } & Ciamis & Tasikmalaya & & & \\
\hline Female & 127 & 168 & 295 & 32 & 10.85 \\
\hline Male & 18 & 35 & 53 & 10 & 18.87 \\
\hline
\end{tabular}

The prevalence of Cryptosporidiumsp related to the age in less than 6 months, 7-12 months and more than 12 months were $14.58 \%, 19.64 \%$ and $9.84 \%$, res-pectively.(Table 3).

Table 3. Prevalence of Cryptosporidium sp oocysts from cattle with age group.

\begin{tabular}{|l|c|c|c|c|c|}
\hline \multirow{2}{*}{ Age } & \multicolumn{2}{|c|}{ Location } & \multirow{2}{*}{ No. examine } & No.positive & Prevalence(\%) \\
\cline { 2 - 5 } & Ciamis & Tasikmalaya & & 7 & 14.58 \\
\hline$<6$ months & 20 & 28 & 48 & 11 & 19.64 \\
\hline $\begin{array}{l}7-12 \\
\text { months }\end{array}$ & 33 & 23 & 56 & 24 & 9.84 \\
\hline $\begin{array}{l}>12 \\
\text { months }\end{array}$ & 92 & 152 & 244 & & \\
\hline
\end{tabular}


The presence of Cryptosporidium sp in this location (Ciamis and Tasikmalaya) can be a source of transmission and reservoir. Factors that can cause infection is the presence of Cryptosporidium $\mathrm{sp}$ sporulating oocyst.Oocysts sporulation influenced by the environment such as temperature, humidity and oxygen. Cattle can be infected with Cryptosporidium sp due to a decrease in immunity and the number of oocysts ingested. (Siverlas, 2010). Transmission of the disease through drinking water and food contaminated with oocysts that have been sporulated (fecal-oral route) (Smith and Nicholas, 2009). Housing and hygiene also influence the spread of infection in cattles, so that possible control measures can be established..

In this study, the prevalence of Cryptosporidium sp related to the sex of cattle showed males higher than in females. This is not in accordance with the research of Ayinmode and Benjamin (2010) which states that the females were higher than males. Actually, males and females have the same risk of infection with Cryptosporidium because it has the same immune system. (Nasir et.al.2009). Cattle can infected by ingested oocysts (Silverlas, 2010).

The prevalence of Cryptosporidium sp related to the age of cattle showed that the age of less than 12 months is higher more than 12 months. This study showed young ages are more sensitive than adults, according to the research of Faubert and Litvinsky (2000).

The results of this study indicate that in Ciamis and Tasikmalaya, cryptosporidiosis was potentially a source of infection and the reservoir. Cryptosporidiosis are zoonotic which can infect animals and humans thus it is necessary to control the disease.

\section{REFERENCES}

[1] Ayinmonde B.A. and Benjamin O.F., 2010. Prevalence of Cryptosporidium infection in cattle from South Western Nigeria. Vet archive, 80(6): 723-731.

[2]Faubert G.M. and Litvinsky Y., 2000. Natural transmission of Cryptosporidiumparvumbetween dams and calves on a Dairy Farm. J.Parasitology, 86(3): 495-500.

[3]Fayer, R., 2004.Cryptosporidium: a water-borne zoonotic parasite.Vet.Parasitol, 126,37-56

[4]Nasir A., Avais M., Khan M.S. and Ahmad N., 2009. Prevalence of Cryptosporidium parvum infection in Lahore (Pakistan) and its association with diarrhea dairy calves. Int. J. Agric. Biol., 11: 221-224.

[5]Santin M., Trout J.M., and Fayer R., 2008. A longitudinal study of cryptosporidiosis in dairy cattle from birth to 2 years of age. Vet.Parasitol, 155, 15-23.

[6] Siverlas C.,2010. Cryptosporidium infection in dairy cattle (Thesis). Uppsala (SW): Swedish University of Agricultura Sciences.

[7]Smith H.V., and Nichols R.A.B., 2009.Cryptosporidium: Detection in water and food. Exp. Parasitol., $19,1-2$ 